\title{
Organization of Automated Human Resource Accounting
}

\author{
Grafova T.O. \\ Russian Customs Academy \\ Rostov State Transport University \\ Rostov-on-Don, Russia \\ Grafova_to@donrta.ru
}

\author{
Kirishchieva V.I. \\ Rostov State Transport University \\ Rostov-on-Don, Russia
}

\author{
Mishchenko O.A. \\ Russian Customs Academy \\ Rostov-on-Don, Russia
}

\begin{abstract}
The article presents the basic principles of accounting and automation of human resources management system. The article covers the investment in the knowledge based capital being increasingly attractive because of its high return. The authors substantiate their position that the knowledge based capital is a necessary business asset, contributing to the increase of value added. The authors suggest the automation of human resources accounting process to be viewed as an opportunity to model the future accounting process based on the application and construction of a derivative balance sheet system. The authors propose to investigate the accounting automation as one of the options for the future state modeling based on the use of a derivative balance sheet system. The use of the knowledge based capital is determined from the point of view of its business efficiency, with its various methods being defined. The authors' developments are presented in the form of constructing a behavioral derivative balance sheet model.
\end{abstract}

Keywords-automation; company; human resources; KBC (knowledge based capital); management accounting; derivative balance sheet

\section{INTRODUCTION}

Nowadays, with a human labor being one of the key factors in scientific and technological progress development and implementation, the allocation of such a category as knowledge based capital is increasingly recognized.

The recent changes in management accounting are connected with the study of such categories as "innovations" and "human resources".

It is human resource and human potential that are the link hiding the greatest reserves to improve and increase modern business efficiency.

Considering the investees, investors have always distinguished such objects as factories, equipment and machinery. But today human is one of the factors of top priority and potential. Every company always puts its employees, their qualifications, level of training and proficiency first to maintain its reputation. The competitive performance of a company, its profit-earning and productive capacity, together with the economic strength, depend on the employees' performance (ranging from processing of the acquired information, order acceptance and financial analysis divisions' work to executive decision-making).

Knowledge based capital, as a unit of knowledge and information flow, becomes key to the competitiveness of both individual enterprises and national economy. The effective application and use of knowledge based capital, the ability to create and increase it are integral to the economic strength of the state, its welfare and social standard of living.

All these provisions served to determine the practical relevance of management accounting of knowledge based capital automation within a company.

The practical and theoretical studies of knowledge based capital, as well as its components, such as human capital assets, consumer's, organizational and structural capitals, engage many Russian and foreign scientists, including: A.N. Shchemelev, V.B. Leontyev, T.O. Grafova, V.L. Inozemtsev, K. Marx, A. Smith, T. Schultz, A. Deli, I. Fisher, and others)

The founders of the theory of knowledge based capital ownership are R. Coase and A. Alchian, while such authors as D. North, R. Posner, S. Peyovich, O. Williamson, and others became their successors. [21,22]

\section{RESEARCH METHODOLOGY}

Modern managers form part of the knowledge based capital as a determinative of a company along with such traditional production factors as labor, land and capital. 
of such capital types as human, structural, consumer's and total

The division of a company's knowledge based capital into types should be considered from the perspective of three aspects, namely the following types of capital:

- stock-in-trade;

- created capital;

- transaction capital.

The use of the knowledge based capital in terms of its business efficiency is determined by various methods, such as:

- expert estimation by third-party agencies;

- a combination of indicators focused on various categories of knowledge based capital; in particular, they include the efficiency of management hierarchy, interaction of a company's structural divisions, decision-making centers distribution, production flexibility and some others [8];

- a company's customer needs indexes, providing the ability to manage business processes and value chain activities with the focus on the factors that are the most significant for customers [6];

- knowledge based capital accounting through the use of the derivative balance sheet elements [18];

- use of transaction accounting, along with accounting engineering tools (behavioral, structural, marketing and other derivative balance sheets) [8].

Some studies have revealed that some types of activities are of key importance for the effective existence of a company. The ability of a company not only to operate, but to be a competitive and profitable one, depends on the effective human resources management with the help of various work and personal motivation, training, staff development, engaging and retaining highly qualified employees. R. Schuler believes that for this purpose such specialized structures, as personnel departments, intended to regulate a company's human resources, performed their duties competently, while the employees of these departments showed more extensive knowledge and skills than the working conditions had earlier required. Moreover, an equally important and even key point in these processes is the consumer and structural capital management; in particular, it concerns the organization of accounting of a company's human resources knowledge based capital use processes.

The process of management accounting of knowledge based capital automation should be started with the initial operator, formed as net assets, aggregated property indicator, studied on the basis of balance sheet and market valuation, with further formation of net liabilities in the form of a disaggregated property indicator in fair value through the use of hypothetical processes.

According to P. Samuelson, all the valuable objects, represented by our property, form assets, while what is lent constitute liabilities. Wealth consists of the net value of the assets belonging to a person at a given point in time [16].

T. O. Grafova developed and patented a number of software products related to the accounting and management knowledge based one with varying degrees of complexity and detailing. These software products include:

- a program for certain types of knowledge based capital;

- a common program of knowledge based capital management with the allocation of free-standing programs;

- a general program of knowledge based capital management.

When creating the process of the knowledge based capital automation accounting, it is necessary to take into account some features of companies, such as:

- awareness of the high significance level of human capital assets in a company's total asset system;

- increasing the share of intangible assets in a company's total interest;

- development of more lawful and flexible labor contracts with employees, along with internal regulations and orders;

- an opportunity for the unsalaried associates to use their knowledge, lack of niche specialization and narrow focus of specialists;

- the definition and analysis of the impact of the structural components of the human resources knowledge based capital use on a company's net assets and net liabilities calculations;

The development of the accounting system as a system of procedures has provided a transition to the use of a set of algorithms, together with a system of various matrices, and engineering tools.

On the one hand, financial, management and strategic accountings are closely interconnected, since the supporting documents act as a source of information for any account, while on the other hand, in general, they represent different systems, each having its own aim to achieve its final result.

In our opinion, strategic management accounting is the most comprehensive, as it includes the following elements:

- construction on the basis of accounting financing items; plan;

- construction a system based on the approved business

- structured accounting in the form of an operating;

- chart of accounts with the use of an enlarged number of control and subsidiary accounts;

- application of engineering accounting methods;

- element-based cost accounting;

- accounting by types of activity, responsibility centers, cost centers and others. 


\section{RESULTS}

In the context of expanding data capability and information field of financial, management and strategic accounting, the engineering accounting methods based on the use of a derived balance sheet system, applied to automate accounting and model the future business development, become relevant.

During the compilation of a behavioral derivative balance sheet we considered the main factors of human capital assets usage (Table 1) [8].

Behavioral theory is focused on the function of management accounting being essentially behavioral. In accordance with this theory, human behavior is influenced by the character and range of accounting systems along with the focus of accountants, ensuring practical development and application of this system.

The application of the behavioral approach is focused on the psychological aspects of decision-making alertness and the corresponding system of human resources accounting:

- budgeting involving its performers for the best understanding of the goals indicated in it;

- formation of profit centers at the company level to evaluate the managers financial performance;

- evaluation and analysis of the number of employees and posting the information into the report forms.

The considered processes result in the fact that the human resources accounting system is aimed at the dynamic development of property in the form of net assets and net liabilities.
Table 1 presents the factors associated with a company's human capital assets usage [8].

TABLE I. FACTORS OF HUMAN CAPITAL ASSETS USAGE

\begin{tabular}{|c|c|}
\hline Factor & Factor characteristics \\
\hline $\begin{array}{l}\text { Creativity in executive thinking; } \\
\text { innovative approach in the process } \\
\text { of making and implementing } \\
\text { managerial decisions }\end{array}$ & $\begin{array}{l}\text { Production thinking; traditional } \\
\text { approach in the process of making and } \\
\text { implementing managerial decisions }\end{array}$ \\
\hline $\begin{array}{l}\text { The system's organization form } \\
\text { improvement and encouraging the } \\
\text { participants, developing the sense } \\
\text { of reliability }\end{array}$ & $\begin{array}{l}\text { Top management experience a sense of } \\
\text { reliability, while the project performers } \\
\text { are due to implement it accurately }\end{array}$ \\
\hline $\begin{array}{l}\text { Selection of a resource breakdown } \\
\text { structure of a flat or mixed } \\
\text { organization of a system for } \\
\text { regulating the development of } \\
\text { concordance between the public } \\
\text { and private economy sectors }\end{array}$ & $\begin{array}{l}\text { The market regulates the concordance } \\
\text { between government and private } \\
\text { agencies in the production industry }\end{array}$ \\
\hline $\begin{array}{l}\text { The organizational system using } \\
\text { related economic development } \\
\text { opportunities, not provided by the } \\
\text { project }\end{array}$ & $\begin{array}{l}\text { The arising unexpected needs being } \\
\text { involved into the main process, and } \\
\text { violating an organizationally focused } \\
\text { commitment to achieving the goal }\end{array}$ \\
\hline $\begin{array}{l}\text { Expectations } \\
\text { ensuring steady and sustainable } \\
\text { development in a competitive } \\
\text { environment }\end{array}$ & $\begin{array}{l}\text { Expectations management is determined } \\
\text { by the implementation of certain } \\
\text { solutions, crisis situations and possible } \\
\text { system destruction }\end{array}$ \\
\hline $\begin{array}{l}\text { Creation of a control system to } \\
\text { limit the value in the process of } \\
\text { socio-economic problems solving }\end{array}$ & $\begin{array}{l}\text { Application of a knowledge control } \\
\text { system while solving the problems } \\
\text { requires significant additional costs, } \\
\text { since it should involve highly skilled } \\
\text { workers }\end{array}$ \\
\hline $\begin{array}{l}\text { Formation of environmental } \\
\text { thinking, organizational and } \\
\text { technical support r of } \\
\text { environmental solutions and } \\
\text { development of environmental } \\
\text { economics principles }\end{array}$ & $\begin{array}{l}\text { High-quality and timely organization of } \\
\text { the approved project implementation } \\
\text { guarantees the environmental } \\
\text { compliance }\end{array}$ \\
\hline
\end{tabular}

TABLE II. BEHAVIORAL DERIVATIVE BALANCE SHEET MODEL

\begin{tabular}{|c|c|c|c|c|c|c|c|}
\hline \multicolumn{2}{|c|}{$\begin{array}{l}\text { Initial operator: basic } \\
\text { accounting equation }\end{array}$} & \multicolumn{2}{|c|}{$\begin{array}{l}\text { Aggregated } \\
\text { behavioral postings }\end{array}$} & \multicolumn{3}{|c|}{$\begin{array}{l}\text { Behavioral derivative Hypothetical posting } \\
\text { balance sheet }\end{array}$} & \multirow{2}{*}{$\begin{array}{l}\begin{array}{l}\text { Hypothetical } \\
\text { derivative } \\
\text { balance sheet }\end{array} \\
\text { Sum }\end{array}$} \\
\hline \begin{tabular}{|l|} 
Elements \\
\end{tabular} & Sum & $\begin{array}{l}\text { Debit } \\
\text { side }\end{array}$ & $\begin{array}{l}\text { Credit } \\
\text { side }\end{array}$ & Sum & Debit side & $\begin{array}{l}\text { Credit } \\
\text { side }\end{array}$ & \\
\hline A. Assets & & & & & & & \\
\hline C. Capital & & & & & & & \\
\hline O. Obligations & & & & & & & \\
\hline Balance sheet & & & & & & & \\
\hline Net assets & & & & & & & \\
\hline Net liabilities & & & & & & & \\
\hline $\begin{array}{l}\text { Synergy } \text { effect o } \\
\text { human capita } \\
\text { assets usage }\end{array}$ & & & & & & & \\
\hline Price component & & & & & & & \\
\hline
\end{tabular}


- calculation of intellectual net assets and intellectual net liabilities. dividing the personnel into several categories, depending on the activity performed (for example, administration, accounting, stockhouse, for-profit sector, etc.). Further evaluation should be based on the Pareto tool, taking into account that 20 percent of employees provide 80 percent of the result, and vice versa, 80 percent of employees provide 20 percent of the result.

This approach enables to determine the synergy effect based on the presented ratios of the human resources categories.

- management accounting in terms of the human resources knowledge based capital can be represented by the evaluation resulted from the application of the key aspects of the knowledge based capital theory;

- employee performance monitoring system (by categories A, B, C);

- job expectation system;

_ - the human resources IQ level detection system; capital;

definition of a company's total knowledge based

- the use of an independent expert estimation system.

According to the results of the behavioral derivative balance sheet formation, patented by the Russian Federal Service for Intellectual Property (Rospatent) (Certificate of application software registration No. 2014615507 Methods of accounting and analytical procurement of knowledge based capital by Grafova T.O, Tishchenko I.A), the synergy effect of the human capital assets use can be determined as[8]:

$$
S e=B p b o-O B U-( \pm G B)
$$

where Se stands for the synergy effect of the human capital assets use;

Bpbo stands for net assets on the behavioral derivative balance sheet;

Gb stand for net liabilities, providing a definition of a price component (a negative price component ensures an increase in the synergy effect of the human capital assets use, while a positive one reduces it).

Behavioral derivative balance sheet (Table 2), enabling to control a company's human capital assets, includes the following iterations:

- the initial operator is the basic accounting equation;

- aggregated behavioral postings;

— behavioral derivative balance sheet;

- hypothetical posting;

— pro forma balance sheet;
The developed derivative balance sheet model for human resources accounting and evaluation can be used as an independent program, implemented in the company, where the people management is of high priority [7].

\section{CONCLUSION}

The estimation of human resources efficiency becomes essential for any company to maintain its stable status and steady position in the market. Creating a system of accounting of automation and measuring of human resources performance factors as one of the main resources, increasing a company's competitiveness, will enable to reach higher performance results.

Designing various bench marks using human resources management engineering methods will allow a company to achieve its goals and move in the direction of its shaped plans and strategies.

\section{References}

[1] I. V. Averchev, Management accounting and reporting Organization and implementation. M.: Vershina. 2006, 512.

[2] Akimochkina T.A. Diagnostics of the organization's human capital. Candidate's thesis. Barnaul. 2007, 23.

[3] A. Appcherch, Management accounting: principles and practice: translated from English; edited by Ya. V. Sokolov, I.A. Smirnova. M.: Finance and Statistics, 2002. 952 p.

[4] E. Atkinson, R. Bakker, R. Kashtan, M. Young, Management Accounting/translated from English. 3rd edition M.: "Williams" publishing house. 2005, 200.

[5] I. F. Vetrova, Intellectual property recognition issues. Statutory accounting. 2007, 12, pp. 74-77

[6] [T. O. Grafova, Methods of accounting engineering tools usage in transaction accounting, Business-engineering. 2011, 11.

[7] T. O. Grafova, O.A. Beloglazova, Strategic management of human resources, "Stroitelstvo - 2010": The International Research and Training Conference materials. Rostov-on-Don: Rostov State University of Civil Engineering. 2010, 250.

[8] T.O Grafova, The system of resource management of knowledge based capital: Monograph. - Rostov-on-Don: Southern Federal University Press, 2010. 450.

[9] Yu. V. Denisevich, Balance method development in statutory accounting. Candidate's thesis. Persianovskiy. 2014, 226.

[10] T.V. Zakharova. Financial, management and strategic accounting of a corporate capital. Rostov-on-Don: Rostov State University of Civil Engineering Press. 2006, 96.

[11] I. V. Zvyagintsev, Ruzakova O.V. Knowledge management system within an enterprise: subject matter, interrelation with management accounting system and their integration perspectives. Contemporary scientific and educational issues. 2015, 1-1, pp. 644.

[12] V. V. Kovalev Goodwill as an accounting category. Statutory accounting. 2005, 8, pp. 52-59.

[13] N. G. Kulakova, Derivative balance sheet usage in strategic business development planning. Construction. Economics: Human resources. Pskov, Polytechnic school, Institute. Pskov. 2010, 14, pp. $123-124$.

[14] D.V. Kurseev Synergy effect estimation. Economic herald of Rostov State University. 2008, 2, vol. 6(3), pp. 58-62.

[15] N.T. Labyntsev, T.A. Stolbunova The derivative balance sheet system usage in trust property accounting. Audit and financial analysis. 2004, 2, pp. 40-43.

[16] Oktepilova V.V. Nobel Prize winner in economics: autobiography, lectures and feedback. 1986-1996, 2009, vol. 2, 477. 
[21] V. E. Fedotov, Intellectual property institution in the market system: theoretical and practical aspects. Candidate's thesis. M.: Financial Academy under the Government of the Russian Federation. 2007, 24. Don: Rostov State University of Civil Engineering Press. 2009, 190.

[18] A. N. Maksimenko, Organization of situational (event-driven) accounting in profit organizations. - Rostov-on-Don: Rostov State University of Civil Engineering Press. 2008, 208.

[19] K. Marx, F. Engels. Capital. Volume 1. Writings. 2nd edition. vol. 23, 788.

[22] Alexsandr S. Kuznetsov. Russian Professor's meeting. Russian Journal of Physical Education and Sport. 2019, 14(1), pp. 17-22. DOI: 10.14526/2070-4798-2019-14-1-18-24

[20] N. P. Rudenko, Management and strategic accounting of financial soundness: theory and practice. - Rostov-on-Don: Rostov State University of Civil Engineering Press. 2007, 229. 